Nig. J. Biotech. Vol. 37(1): 94-100 (June 2020)

ISSN: 01891731

Available online at

http://www.ajol.info/index.php/njb/index

and www.biotechsocietynigeria.org

DOI: https://dx.doi.org/10.4314/njb.v37i1.10

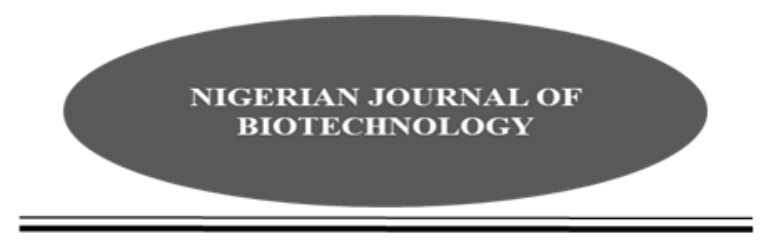

\title{
Effects Of Calotropis procera Latex on Biochemical and Hematological Parameters in Albino Rats
}

\author{
Samuel, $K_{.}{ }^{1 *}$ and Sudi Y. I. ${ }^{1,2}$ \\ ${ }^{1}$ Department of Biochemistry, Faculty of Science, Adamawa State University, PMB 25, Mubi, Adamawa \\ State, Nigeria. \\ ${ }^{2}$ North East Zonal Biotechnology Centre of Excellence, University of Maiduguri, Borno State, Nigeria.
}

\begin{abstract}
Calotropis procera is a wild-growing plant that belongs to the family Asclepiadaceae, commonly found in the tropical regions and is used in the treatment of diseases such as ulcer, inflammation, wound healing, etc. This confers to the increased use of medicinal plants as the major source of traditional medicine worldwide. This study is aimed at evaluating the toxicological effects of Calotropis procera latex on biochemical and hematological parameters in albino rats with a view to understanding the safety of the latex following systemic use. Fifteen (15) albino rats were divided into five groups of three rats each. Group one served as the control, group two received $0.05 \mathrm{ml}$ of the latex solution per $\mathbf{k g}$ body weight of the rats , group three received $0.2 \mathrm{ml}$ of the latex solution per $\mathrm{kg}$ body weight of the rats, group four received $0.4 \mathrm{ml}$ of the latex solution per $\mathrm{kg}$ body weight of the rats , while group five received $0.6 \mathrm{ml}$ of the latex solution per $\mathrm{kg}$ body weight of the rats for 14 days. Biochemical evaluations revealed a significant increase in the serum levels of aspartate aminotransferase $\left(83.33 \pm 1.76^{c}\right)$ and total bilirubin $\left(6.27 \pm 4.44^{b}\right)$ and a progressive decrease in albumin $\left(3.93 \pm 0.04^{a}\right)$ with increased concentration of the latex. There was no significant change in the levels of alanine aminotransferase and alkaline phosphatase in all the treated groups. Hematological analyses revealed a significant $(\mathrm{p}<0.05)$ decrease in packed cell volume $\left(31.33 \pm 1.76^{\mathrm{a}}\right)$, hemoglobin $\left(10.43 \pm 0.59^{\mathrm{a}}\right)$, red blood cell count $\left(3.90 \pm 0.06^{\mathrm{a}}\right)$ and total white blood cell count $\left(4.10 \pm 0.15^{\mathrm{a}}\right)$ in all the treated groups compared to the control. In conclusion, the results of this study suggest that Calotropis procera latex is relatively toxic as observed in the blood and biochemical parameters related to liver function. Hence, it is recommended that caution should be taken in its use for the treatments of diseases such as wound healing as exposure to the circulatory system can cause vulnerability to its toxic effects.
\end{abstract}

Keywords: Albino rats, Toxicity, Calotropis procera, latex, biochemical, hematological parameters *Correspondence: samuelkadauyina@gmail.com; +234(0)9065441532

\section{Introduction}

Calotropis procera (Tumfafiya in Hausa) is a plant with a wild-growing ability that has been used for the treatment of a variety of human disease conditions such as wound healing, tumors, inflammation, ulcers, leprosy, etc (Abidemi et. al., 2017). The plant is known to release large quantities of milky saps (latex) when its tissues are mechanically damaged. This may be a 
mechanism of defense of the plant against predators. A number of researches have been conducted on the plant which established it as the major source of drugs used in the modern era (Ali, 2015). Calotropis procera is among the plants not eaten by grazing animals due to its toxicological characteristic. The latex has been used traditionally in making poisonous arrows. It is toxic to human eyes, producing impaired vision (dimness) as well as photophobia. Plants have been used as characteristic drugs to cure a variety of diseases worldwide. This medicinal action of plants is due to the presence of phytochemicals or bioactive compounds in them (Hossaim et. al., 2019). Liver is the major organ that plays an essential role in the metabolism of chemicals through phase one and phase two metabolic reactions. Any injury to the liver may affect the coordinated metabolic reactions in the liver and may lead to serious health problems in the human body (Halilu et. al., 2012). Drugs, particularly anti-tubercular drugs and general anesthetics, can cause liver damage. The liver can sometimes be damaged when in contact with some chemicals called hepatotoxins (Mohan, 2002). Liver response to toxic chemical compounds depends solely on the concentration of the toxicants in the body, distinct enzymes activity and blood concentration gradient of the substances. In disease conditions, high or low values of blood cells chemicals and/or enzymes are observed (Almasio et. al., 2011).

Biochemical and hematological parameters comprise biomarkers such as packed cell volume (PCV), red blood cell count (RBC), white blood count (WBC), hemoglobin, alanine aminotransferase (ALT), aspartate transferase (AST), Alkaline phosphatase (ALP), albumin, bilirubin, etc. The biomarkers are important in checking for infection, assessing disease conditions and monitoring treatment progress in health care practices (Wararut et. al., 2012). The extent of harmful or beneficial effects of xenobiotic compounds including plant extracts on blood and other body fluids can be determined by assessing the biochemical and hematological parameters levels (Ashafa et. al., 2009). Bloodrelated functions of different chemical compounds can as well be analyzed by assessing the blood level of these biomarkers (Yakubu et. al., 2007). According to Yang et. al. (2014), this may be due to the fact that blood is transported to the liver (the organ responsible for metabolism) through the portal veins which carries blood that contains digested nutrients from the gastrointestinal (GI) tract, and hepatic arteries that carries oxygenated blood from the lungs. Thus, hepatocytes release AST and ALT enzymes as biomarkers into the blood stream.

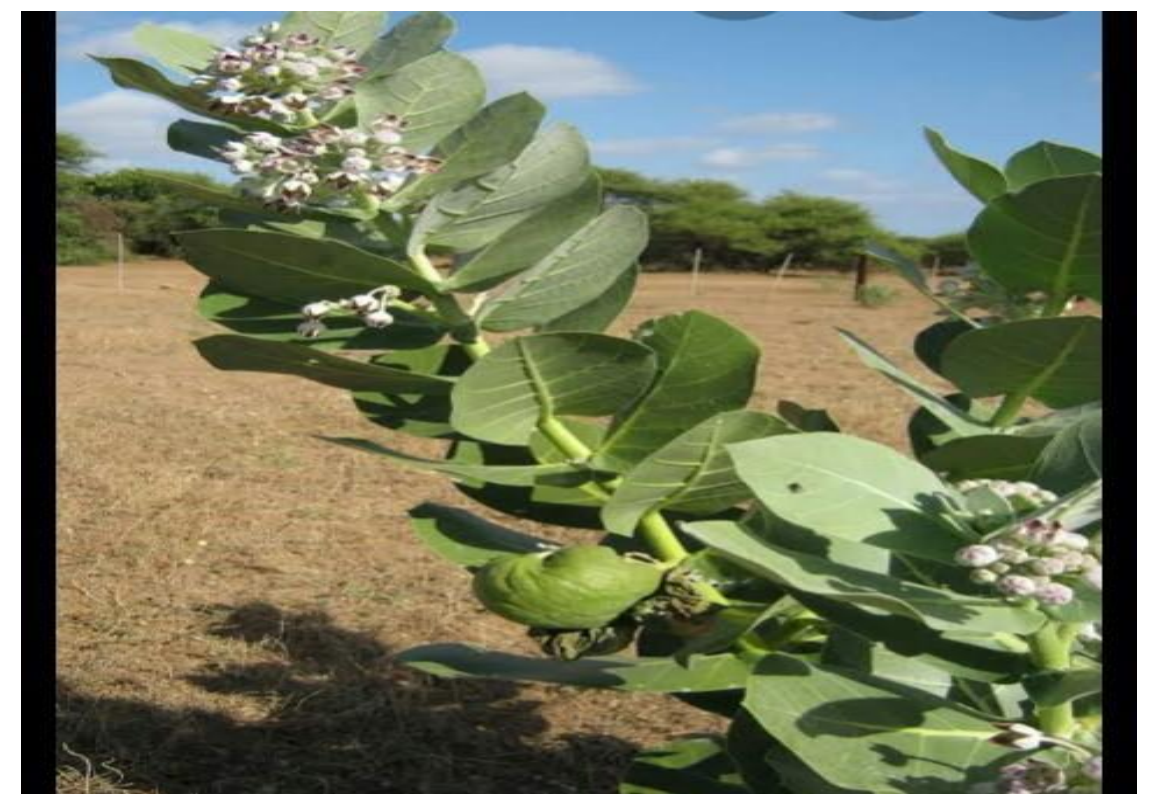

Figure 1: Pictorial Representation of Calotropis procera Plant. 


\section{Materials and Methods}

\section{Collection and Preparation of Plant Material}

Calotropis procera latex was collected from different sites at Adamawa State University, Mubi, Adamawa State, Nigeria. It was identified and authenticated at the Department of Botany, Adamawa State University, Mubi. Preparation of the plant extract was carried out in accordance with the method of Kareem et. al. (2003). Fresh latex was collected from healthy plants by making small incisions on the stems and on the leaf stalks that are closest to the leaves, allowing the latex to flow into a clean container aseptically. The latex was gently handled so as to maintain its integrity during transport to the laboratory. The latex was triturated using glass mortar and pestle so as to finely disperse the colloidal portion of the latex and to make it more soluble when dispersed in water. Different doses were prepared by diluting the raw latex with distilled water.

\section{Animals}

Albino rats of both sexes were purchased from Mubi, Adamawa state. All procedures involving the animals were duly conducted with strict adherence to guidelines and procedures. Animal experiments were carried out according to the guidelines of the Animal Ethical Committee of Adamawa State University, Mubi.

\section{Qualitative Phytochemical Screening of Calotropis procera Latex \\ The qualitative phytochemical constituents in the latex of Calotropis procera were determined as described by Hassan et al., (2017). Tannins, Flavonoids, Alkaloids, Terpenoids, saponins, cardiac glycosides, steroids and phenols were tested for.}

\section{Acute Toxicity Test}

An acute toxicity study was carried out using the method of Abidemi et. al. (2017) with little variation. Six (6) rats were randomly divided into 3 groups of 2 rats per group and were respectively given doses of the latex solution at $0.05 \mathrm{ml} / \mathrm{kg}, 0.1 \mathrm{mg} / \mathrm{kg}$ and $0.2 \mathrm{ml} / \mathrm{kg}$ of the rats body weights orally . The rats were all placed under the same conditions where they were observed for signs of toxicity which included grooming, rearing, respiratory distress and mortality e.t.c for the first $4 \mathrm{~h}$ and $24 \mathrm{~h}$. Another Six (6) rats were randomly divided into 3 groups of 2 rats per group and were respectively given doses of the substance at $0.4 \mathrm{ml} / \mathrm{kg}, 0.8 \mathrm{mg} / \mathrm{kg}$ and $1 \mathrm{ml} / \mathrm{kg}$ of the rats body weights orally . The rats were kept under the same conditions and observed for signs of toxicity which included but not limited to grooming, rearing, respiratory distress and mortality for the first critical $4 \mathrm{~h}$ and $24 \mathrm{~h}$.

\section{Experimental Design}

Adult Albino rats (both sexes) were used for this study. They were allowed for seven days to acclimatize in a standard metal gauge. The animals had free access to food and water, and were distributed into groups and housed in cages (three per cage).

The rats were randomly divided into five (5) groups (of three rats each). Group one served as control and received distilled water. Group two, three, four and five as test groups received 0.05 $\mathrm{ml} / \mathrm{kg}, 0.2 \mathrm{ml} / \mathrm{kg}, 0.4 \mathrm{ml} / \mathrm{kg}$ and $0.6 \mathrm{ml} / \mathrm{kg}$ body weight of Calotropis procera latex solution, respectively. Treatment was done for 14 days. All the animals were anaesthetized 24 hours after the administration of the final doses and blood samples were collected.

Sample Collection for Biochemical and Hematological Parameters

This was done in accordance with Abidemi et. al. (2017). On the 14th day of the experiment, all the rats were euthanized after Diethyl ether inhalation and blood was collected by sacrificing the rats. Portions of the blood were collected into K+ EDTA bottles for estimation of packed cell volume (PCV), hemoglobin concentration $(\mathrm{Hb})$, red blood cell count (RBC) and white blood cell counts (WBC) using an automated blood analyzer. Other portions of the collected blood samples were dispensed into non-heparinized bottles, allowed to clot and centrifuged at 3500 rpm for $10 \mathrm{~min}$. The serum was separated, stored at - $\quad 4^{\circ} \mathrm{C}$ and used for evaluation of biochemical parameters which included: alanine transaminase (ALT), aspartate transaminase (AST) levels, alkaline phosphatase (ALP), bilirubin and albumin. 


\section{Biochemical Assays}

Randox commercial kits were used to determine the concentrations of alanine aminotransferase, aspartate aminotransferase, alkaline phosphatase, albumin and total bilirubin, according to the methods described by Olorunfemi et al. (2006).

Statistical Analysis

Data were expressed as Mean+ SEM and were analyzed by one-way ANOVA and Tukey's test. $p<0.05$ were taken as significant $(P<0.05)$ differences among the five experimental groups.

Results

\section{Acute Toxicity $\left(L D_{50}\right)$}

The result of the oral acute toxicity of Calotropis procera latex was found to be $1.0 \mathrm{ml} / \mathrm{kg}$ body weight and $50 \%$ mortality was recorded in the group of experimental rats.

Qualitative Phytochemical Screening

Table 1 shows the results of the qualitative phytochemical constituents present in Calotropis procera latex. The result showed the presence of tannins, saponins, terpenoids, flavonoids, glycosides, alkaloids and steroids while phenol was absent in the plant latex.

Table 1: Qualitative Analyses of Phytochemical Constituents of Calotropis procera Latex

$\begin{array}{ll}\text { Phytochemicals } & \text { Result }\end{array}$

$\begin{array}{lr}\text { Alkaloids } & + \\ \text { Flavonoids } & + \\ \text { Terpenoids } & + \\ \text { Tannins } & + \\ \text { Saponins } & + \\ \text { Glycosides } & + \\ \text { Phenols } & +\end{array}$

Key: + Means Present - Means Absent

\section{Biochemical Parameters Analysis}

Table 2 shows the effect of Calotropis procera latex on some biochemical parameters related to liver function. The serum levels of ALT and ALP activity showed no significant difference at $\mathrm{p}<0.05$ compared to the control. However, there was a progressive decrease in the concentration of albumin in all the treated groups compared to the control. The latex produced a significant increase in the levels of aspartate aminotransferase and total bilirubin in the treated groups compared to the control. 
Samuel et al./ Nig. J. Biotech. Vol. 37 Num. 1 : 94-100 (June 2020)

Table 2: Effect of Calotropis procera Latex on Some Biochemical Parameters Related to Liver Function

\begin{tabular}{llllll} 
Groups & AST $(\mathbf{U} / \mathbf{L})$ & ALT $(\mathbf{U} / \mathbf{L})$ & ALP $(\mathbf{U} / \mathbf{L})$ & $\begin{array}{l}\text { Albumin } \\
(\mathbf{g} / \mathbf{d L})\end{array}$ & $\begin{array}{l}\text { T.Bilirubin } \\
(\boldsymbol{\mu m o l} / \mathbf{L})\end{array}$ \\
\hline Control & $59.33 \pm 2.91^{\mathrm{a}}$ & $54.67 \pm 2.67^{\mathrm{a}}$ & $41.98 \pm 0.61^{\mathrm{a}}$ & $4.47 \pm 0.05^{\mathrm{a}, \mathrm{b}}$ & $5.70 \pm 5.23^{\mathrm{b}}$ \\
& & & & & \\
$0.05 \mathrm{ml} / \mathrm{kg} \mathrm{b.w}$ & $61.33 \pm 0.67^{\mathrm{a}, \mathrm{b}}$ & $53.66 \pm 2.33^{\mathrm{a}}$ & $40.48 \pm 2.43^{\mathrm{a}}$ & $4.40 \pm 0.03^{\mathrm{b}}$ & $4.40 \pm 0.03^{\mathrm{a}}$ \\
& & & & & \\
$0.2 \mathrm{ml} / \mathrm{kg}$ b.w & $68.00 \pm 1.15^{\mathrm{b}}$ & $50.33 \pm 0.88^{\mathrm{a}}$ & $40.64 \pm 4.52^{\mathrm{a}}$ & $4.32 \pm 0.17^{\mathrm{b}}$ & $5.83 \pm 0.92^{\mathrm{b}}$ \\
& & & & & \\
$0.4 \mathrm{ml} / \mathrm{kg}$ b.w & $77.00 \pm 1.00^{\mathrm{c}}$ & $50.33 \pm 0.83^{\mathrm{a}}$ & $38.38 \pm 0.87^{\mathrm{a}}$ & $4.27 \pm 0.03^{\mathrm{a}, \mathrm{b}}$ & $5.16 \pm 0.64^{\mathrm{a}}$ \\
& & & & & \\
$0.6 \mathrm{ml} / \mathrm{kg}$ b.w & $83.33 \pm 1.76^{\mathrm{c}}$ & $42.00 \pm 1.15^{\mathrm{a}}$ & $47.24 \pm 0.32^{\mathrm{a}}$ & $3.93 \pm 0.04^{\mathrm{a}}$ & $6.27 \pm 4.44^{\mathrm{b}}$ \\
\hline
\end{tabular}

Values are expressed as mean \pm SEM, $(n=3)$. Values along the same column with the same superscript are not significantly different; values with different superscripts are significantly different $(p<0.05)$.

Hematological Parameters Analysis

Table 3 shows the effect of Calotropis procera latex on hematological parameters. The levels of PCV, HB and RBC decreased with increased oral dose of the plant latex. Increased levels of WBC were observed initially, but later decreased at the dose of $0.6 \mathrm{ml} / \mathrm{kg}$ Calotropis procera latex. The treated groups showed a significant difference at $\mathrm{p}<0.05$ in all the parameters compared to the control group.

Table 3: Effects of Calotropis procera Latex on Hematological Parameters

\begin{tabular}{llllc}
\hline Group & PCV (\%) & HB (g/dL) & $\begin{array}{l}\text { WBC( } \mathbf{x 1 0}^{\mathbf{3}} \\
\left.\mathbf{c e l l s} / \mathbf{m m}^{\mathbf{3}}\right)\end{array}$ & RBC (x 10 12/L) \\
\hline Control & $37.67 \pm 0.67^{\mathrm{b}}$ & $12.43 \pm 0.29^{\mathrm{b}}$ & $5.47 \pm 0.24^{\mathrm{b}}$ & $4.73 \pm 0.03^{\mathrm{c}}$ \\
$0.05 \mathrm{ml} / \mathrm{kg}$ latex & $38.33 \pm 0.33^{\mathrm{b}}$ & $12.25 \pm 0.13^{\mathrm{b}}$ & $5.40 \pm 0.20^{\mathrm{b}}$ & $4.57 \pm 0.12^{\mathrm{b}, \mathrm{c}}$ \\
$0.2 \mathrm{ml} / \mathrm{kg} \mathrm{latex}$ & $36.00 \pm 0.58^{\mathrm{b}}$ & $12.03 \pm 0.18^{\mathrm{b}}$ & $5.67 \pm 0.13^{\mathrm{b}}$ & $4.47 \pm 0.27^{\mathrm{a}, \mathrm{b}, \mathrm{c}}$ \\
$0.4 \mathrm{ml} / \mathrm{kg} \mathrm{latex}$ & $35.00 \pm 0.58^{\mathrm{a}, \mathrm{b}}$ & $11.63 \pm 0.20^{\mathrm{a}, \mathrm{b}}$ & $5.50 \pm 0.17^{\mathrm{b}}$ & $4.03 \pm 0.009^{\mathrm{a}, \mathrm{b}}$ \\
$0.6 \mathrm{ml} / \mathrm{kg}$ latex & $31.33 \pm 1.76^{\mathrm{a}}$ & $10.43 \pm 0.59^{\mathrm{a}}$ & $4.10 \pm 0.15^{\mathrm{a}}$ & $3.90 \pm 0.06^{\mathrm{a}}$ \\
\hline
\end{tabular}

Values are expressed as mean \pm SEM, $(n=3)$. Values along the same column with the same superscript are not significantly different; values with different superscripts are significantly different $(p<0.05)$.

\section{Discussion}

The various chemical constituents in plants are known as phytochemical compounds of which some are considered as secondary metabolites. The bioactive compounds are directly responsible for numerous medicinal activities of plants, such as anti-inflammatory, antifungal, antibacterial and antimalarial activity. Some serve as defense factors against pests (Harbone, 2000). The qualitative phytochemical screening revealed that phenols are absent in the plant latex. The 
absence of phenols indicates the lack of antioxidant activity of the plant latex, as the capacity of plants to scavenge free radicals and reduce lipid oxidation is attributed to the antioxidant potentials of phenolic compounds (Hossain and Nagooru, 2013).

According to Basak et. al, (2009) as reported by Abidemi et. al. (2017), Calotropis procera contain chemicals like calcilin, calotropeginin, calotrotoxin and gigantin which have toxicity potentials. These compounds may be responsible for the effects observed in rats treated with high doses of the latex in the acute toxicity studies. Absence of adverse effect in rats treated with lower doses may be due to low bioavailability of these compounds in the circulatory system (Abidemi et. al., 2017).

As a result of the increased ethnomedical use of Calotropis procera, it has become a necessity to determine its level of toxicity to humans, especially. This is achieved through assessing the biochemical and hematological parameters following administration of chemical compounds. Elevated activities of enzyme markers (AST and ALT) as well as decreased concentration of the enzymes may be an indication of liver damage, which could be due to exposure to toxic exogenous compounds or agents (Olorunfemi et. al., 2006). Hepatic damage leads to increased leakage of enzymes in circulation and reduced ability to synthesize proteins such as albumin. This can be reflected in the increased concentration of AST and ALT and the reduced albumin concentration (Abidemi et. al., 2017). Bilirubin (an organic compound formed during the normal and abnormal destruction of red blood cells by the reticuloendothelial system) concentration may be associated with hemolytic jaundice, pernicious anaemia, hemolytic anaemia, etc. Increased concentration of total bilirubin in the blood may be due to liver damage that leads to reduced ability of the liver to conjugate bilirubin for removal through the kidneys in urine. Decrease in the level of albumin may result from liver damage caused by some chemical compounds in the latex that reduce the ability of the liver to synthesize albumin

Hematological analysis revealed that there was a progressive decrease in packed cell volume (PCV), hemoglobin, red blood cell counts (RBC) and white blood cell count (WBC), with increasing concentrations of the Calotropis procera latex. This is similar to the findings of Abidemi et. al. (2017). The damage caused by the latex on red blood cells may be related to red cell lysis caused by the plant latex that caused reduced RBC and hemoglobin levels in the blood. Decrease in RBC and hemoglobin concentration may result in hypoxia (reduced oxygen transport and delivery to body tissues) which is detrimental to human health. The WBC showed an initial rise in group 3 and 4 , similar to the findings of Udoh et. al. (2016) but group 5 showed a marked decrease in WBC count. Immunosuppression of white blood cells can be caused by chemical compounds including extracts from plants as observed in this study.

\section{Conclusion}

This study suggests that Calotropis procera latex contains the phytochemicals alkaloids, tannins, saponins, terpenoids, glycosides, flavonoids and steroids while phenols are absent. The study also suggests that the latex is toxic to both the liver and blood parameters, though it may be relatively safe when used acutely especially through the oral route in low doses in rats. Its use in woundhealing and prevention of keloid formation, however, involves its direct contact with the circulatory system which may produce toxic effects. The marked progressive decrease in the levels of the hematological parameters, and rise in some of the liver indices with increasing concentration of the latex indicates signs of toxicity. It is recommended that further research should be carried out in order to check the effects of the plant latex on the activities or health of other organs and tissues apart from blood and the liver.

\section{Acknowledgement}

The authors wish to thank Mr. Janyo of Chemistry Research Lab. Adamawa State University, Mubi, and Mr. Christopher Danladi of DNA Laboratory Mubi, Adamawa State, for their guide in Biochemical and Hematological analyses respectively.

\section{References}

Abidemi, E., Abiodun, A., Rhaman, A. B. and James, A. (2017). An experimental study of the toxicity effectsof Calotropis procera (Aiton) 
Asclepiadaceae in Sprangue-dawley rats. W. J. Pharma. Res. 6(11): 42-55.

Ali, I. A. (2015). Biochemical effects of Calotropis procera on hepatotoxicity. J. Biomed. Res. Ther. 2(12): 446-453.

Almasio, P. L., Licata, A. and Randazzo, C. (2011). Drugs and toxins effects on the liver. Liver Biopsy in Modern Medicine, 9(1): 117-134.

Ashafa, A. O. T., Yakubu, M. T., Grierson, D. S. and Afolayan, A. J. (2009). Toxicological evaluation of the aqueous extract of Felicia muricata Thunb. leaves in Wistar rats. Afr. J. Biotech. 8(6): 949-954.

Basak, S. K., Bhaumik, A., Mohanta, A. and Singhal, P. (2009). Ocular toxicity by latex of Calotropis procera (Sodom apple). Ind. J. Ophthalmol. 57(3): 232-234.

Halilu, M., Abubakar, A., Garba, M. and Isah, A. (2012). Antimicrobial and Preliminary Phytochemical studies of Methanol Extract of Root Bark of Crossopteryx febrifuga (Rubiaceae). J. Appl. Pharma. Sci. 2(12): 66-70.

Harbone, J. B. (2000). Phytochemical methods: A guide to modern techniques of plant analysis. 2nd edition. London Chapman and Hall, 54 - 84.

Hassan, M. H., Ismail, M. A., Ahmed, M. M. and Ahmed, A. S. (2017). Phytochemical and antimicrobial of latex of Calotropis procera and its silver nanoparticles against some reference pathogenic strains. Inter. J. Health \& Environ. 5(3): 65-75.

Hossain, A. H., Hendrikx, A. and Punt, P. J. (2019). Identification of novel citramalate biosynthesis pathways in Aspergillus niger. Fungal Biology and Biotechnology, 6(19): 8487.

Hossain, M. A. and Nagooru, M. R. (2013). Biochemical profiling and total flavonoids contents of leaves extract of endemic medicinal plants. J. Pharma. 3(24): 25-30.

Kareem, S. O., Akpan, I. and Osho, M. B. (2003). Calotropis procera (Sodom apple): A potential material for enzyme purification. J. Bio. Tech. 87(1): 133-135.
Mohan, H. (2002). The liver, biliary tract and exocrine pancreas. Text Book of Pathology, Jaypee Brothers Medical Publishers (P) Ltd. New Delhi, 4: 569-630.

NHANES. (2000). Biochemical profile in refrigerated serum: Laboratory procedure manual.

Olorunfemi, A. E., Arit, E., Iboro, I. and Ahnold, C. I. (2006). Biochemical changes in serum of rat treated with aqueous extract of the fruit of Telferia occidentalis. Afr. J. Biomed. Res. 9(2): 235-237

Udoh, E. Y., Jonah, S. A. and Iyeopu, M. S. (2016). Acute and sub-acute toxicity studies on the aqueous extract of Calotropis procera latex. W. J. Pharma. Res. 2(1): 77- 95.

Wararut, B., Supap, C., Kanokporn, D. J. and Wardrop, K. J. (2012). Evaluation of biochemical, hematological and histopathological parameters of albino rats treated with Stemona aphylla Craib. Extract. J. Med. Plants Res. 6(27): 4429-4435.

Yakubu, M. T., Akanji, M. A. and Oladiji, A. T. (2007). Haematological evaluation in male albino rats following chronic administration of aqueous extract of Fadogia agrestis stem. Pharma. Mag. 3:34 